\title{
Random Amplified Polymorphic DNA Typing of Clinical and Environmental Aeromonas hydrophila Strains from Limpopo Province, South Africa
}

\author{
J.N. Ramalivhana', C.L. Obi ${ }^{2}$,A. Samie 3 , C. Labuschagne ${ }^{4}$, and G.F.Weldhagen ${ }^{5}$ \\ 'College of Agriculture and Environmental Sciences, School of Agriculture and Life Sciences, University of South Africa, Pretoria, \\ South Africa, ${ }^{2}$ Academic and Research Division, Walter Sisulu University, Nelson Mandela Drive, Mthatha, Eastern Cape, \\ South Africa, ${ }^{3}$ Department of Microbiology, University of Venda, Private Bag X5050, Thohoyandou 0950, South Africa, ${ }^{4}$ Inqaba \\ Biotechnological Laboratory, Pretoria, South Africa, and ${ }^{5}$ Infectious Diseases Unit, Department of Internal Medicine, Faculty of \\ Health Sciences, University of Pretoria and Molecular Biology Laboratory, AMPATH National Laboratory Service, \\ Pretoria , South Africa
}

\begin{abstract}
The aim of the present study was to determine the genetic relatedness of strains isolated from diarrhoeal stool and water specimens collected from water-storage containers from different geographical areas in the Limpopo province. In total, 32 Aeromonas strains isolated from stool specimens collected from HIV/AIDS patients suffering from gastroenteritis and their household drinking-water stored in 20-L and 25-L containers were analyzed by random amplified polymorphic DNA PCR (RAPD). The RAPD fingerprints obtained proved reproducible when repeated on three different occasions using whole-cell DNA isolated from the Aeromonas strains. In total, 12 unique RAPD fingerprints were found. The results revealed a tendency of the isolates to cluster according to their origin of isolation (best-cut test 0.80 and bootstrap values $>50 \%$ ). However, a certain degree of similarity was also observed between isolates of water sources and clinical sources which indicated genetic relatedness. There were also genetic similarities between the clinical and the environmental strains of Aeromonas spp. isolated from different geographical areas. This study has demonstrated the genetic relatedness of Aeromonas hydrophila isolates from household drinking-water and clinical sources in South Africa, which may be due to cross-contamination from water to patients or vice-versa. This observation is of publichealth significance, particularly in the era of HIV/AIDS. This study points to the importance of monitoring and evaluating infection-control measures for improved hygiene and to prevent cross- contaminations.
\end{abstract}

Key words: Aeromonas; Aeromonas hydrophila; Diarrhoea; Genotyping; South Africa

\section{INTRODUCTION}

The genus Aeromonas comprises several species of oxidase-negative and catalase-positive, glucosefermenting, facultative anaerobic, Gram-negative, rod-shaped, motile and non-motile bacteria (1). They are widely distributed in nature, especially in aquatic environments and have been isolated

Correspondence and reprint requests should be addressed to:

Dr. A. Samie

Department of Microbiology

University of Venda

Private Bag X5050

Thohoyandou 0950

Limpopo Province

South Africa

Email: samieamidou@yahoo.com OR

samie.amidou@univen.ac.za

Fax: +(27) 0159628648 from various raw foods, such as fish and vegetables. These bacteria are widely found in surface water and sewage; they also occur in untreated and treated drinking-water (2). In humans, Aeromonas species are responsible for gastroenteritis, chronic diarrhoea, wound infections, respiratory tract infections, peritonitis, urinary tract infections, and septicaemia (3). Aeromonas spp. have been implicated as diarrhoea-causing agents in both HIV-positive and HIV-negative patients in South Africa (4). However, no study has determined the possible genetic relationship between environmental and clinical strains.

Genomic fingerprinting methods, such as random amplified polymorphic DNA PCR (RAPD) typing, are regarded as accurate methods for the typing of microorganisms for epidemiological purposes (5). 
Although Aeromonas spp. have been described in South Africa, there is a paucity of studies that have determined the possible source of human infections, including the phylogenetic relatedness between clinical and environmental isolates. In the present study, RAPD was employed to determine the genetic relatedness of strains isolated from diarrhoeal stool and water specimens collected from water-storage containers from different geographical areas in the Limpopo province, South Africa.

\section{MATERIALS AND METHODS}

\section{Study sites and ethical clearance}

Stool samples and household drinking-water samples were collected from HIV and AIDS patients in different locations in the Limpopo province, including Belabela, Madombidzha, Mankweng (Polokwane), and Musina. Aeromonas spp. were isolated from these samples and characterized as previously described (6). Thirty-two strains of Aeromonas hydrophila from these samples were used in the present study for beta-lactamase production, antibiotic susceptibility as previously described (6), and in genotyping studies. The geographical origins and sources of the strains used in the study are indicated in the table. Ethical clearance was obtained from the Ethics and Research Committee of the University of Venda, Thohoyandou, Limpopo province, South Africa.

\section{Genomic DNA extraction}

Extraction of whole-cell DNA was performed by a precipitation-based method as described previously (7). Briefly, the cells were lysed by the addition of SDS (Promega, Madison, WI) and lysozyme (Sigma Chemical Co. St. Louis, MO, USA) with incubation at $37^{\circ} \mathrm{C}(\mathrm{QBT} 2$ heating block, Grant Instruments Ltd., Cambridge, United Kingdom) for one hour. The DNA was further isolated using chloroform/ isoamyalcohol (24:1) (Sigma Chemical Co., St. Louis, MO, USA) and precipitated with isopropanol (Merck, Darmstadt, Germany) at $-20{ }^{\circ} \mathrm{C}$ overnight and stored at $-20^{\circ} \mathrm{C}$ until further analysis.

\section{Confirmation of Aeromonas hydrophila} identity by I6S rRNA gene-sequencing

All the Aeromonas strains used in the present study were identified as previously described and confirmed by PCR analysis and sequencing of the $16 \mathrm{~S}$ rRNA gene for two isolates. The 16S rRNA gene sequence was PCR-amplified in a Perkin-Elmer GeneAmp PCR System 2400 thermocycler as previously described (5)
All DNA extractions and PCR products were verified by gel electrophoresis for one hour in a $1 \%$ agarose gel (Pronadisa, Madrid, Spain) containing ethidium bromide (Promega, Madison, WI, USA) and the images captured using a digital gel documentation system (DigiDoc-It imaging system, UVP, Upland, CA, USA).

\section{Random amplified polymorphic DNA analysis of strains}

Random amplified polymorphic DNA analysis was performed on 32 isolates using whole-cell DNA as template to determine the genetic relationships of isolates according to a modified method previously described $(8,9)$ using three different primers to obtain a banding pattern representative of the whole genome. All the samples were run at least twice using each primer.

\section{Analysis of RAPD fingerprints}

The amplification products were electrophoresed in $1.5 \%$ agarose gel in Tris-borate buffer. Computer analyses were carried out using the GelCompar II software (version 3.0; Applied Maths, Kortrijk, Belgium). Similarity between fingerprints was calculated with the Dice coefficient. Cluster analysis was performed using the unweighted pair-group method with average linkages (UPGMA).

\section{RESULTS}

The fingerprints of the isolates generated between 2 and 17 bands ranging from 100 to $3,500 \mathrm{bp}$. The banding patterns proved reproducible when repeated on two separate occasions. Random amplified polymorphic DNA fingerprints which possessed more than 90\% similarity were considered identical and were assigned an RAPD type. On this basis, 12 unique RAPD types were assigned as shown in the figure. The isolates and the specimen types from which the isolates were obtained are shown in the table.

There was a difference between the clinical and the environmental strains. Type 1, for example, was composed of four clinical strains, and type 4 was composed of five clinical strains while type 7 was composed of all four environmental strains. However, there was a mixture of clinical and environmental strains in the same type.

\section{DISCUSSION}

We had previously isolated and characterized Aeromonas spp. from stool and water samples from different areas in the Limpopo province (6). However, 


\begin{tabular}{|c|c|c|c|c|}
\hline Locality & Isolate* & $\begin{array}{l}\text { RAPD } \\
\text { type }\end{array}$ & $\begin{array}{l}\text { Beta-lactamase } \\
\text { production }\end{array}$ & Antibiotic resistance combination \\
\hline Belabela & $6165 S$ & 1 & Negative & Ampicillin \\
\hline Belabela & $6168 S$ & 1 & Negative & Ampicillin \\
\hline Belabela & $6173 S$ & 4 & Negative & $\begin{array}{l}\text { Amikacin, ampicillin, cefotaxime, } \\
\text { nitrofurantoin, tobramycin }\end{array}$ \\
\hline Belabela & $6197 S$ & 4 & Positive & $\begin{array}{l}\text { Amikacin, ampicillin, cefazolin, } \\
\text { cefotaxime }\end{array}$ \\
\hline Belabela & $6237 S$ & 5 & Positive & $\begin{array}{l}\text { Ampicillin, cefotaxime, nitrofurantoin, } \\
\text { tobramycin }\end{array}$ \\
\hline Belabela & $6164 \mathrm{E}$ & 5 & Negative & $\begin{array}{l}\text { Ceftriaxone, ciprofloxacin, } \\
\text { gentamicin, ampicillin }\end{array}$ \\
\hline Belabela & $6249 \mathrm{E}$ & 6 & Positive & $\begin{array}{l}\text { Amikacin, ampicillin, cefazolin, } \\
\text { cefotaxime, nitrofurantoin, tobramycin }\end{array}$ \\
\hline Belabela & $6241 \mathrm{E}$ & 7 & Negative & Nitrofurantoin, amikacin, ampicillin \\
\hline Belabela & $6238 S$ & 12 & Negative & Nitrofurantoin \\
\hline Belabela & $6248 \mathrm{E}$ & 11 & Negative & Ampicillin \\
\hline Madombidhza & $6171 S$ & 1 & Negative & Ampicillin \\
\hline Madombidhza & $6170 S$ & 4 & Negative & $\begin{array}{l}\text { Ampicillin, nitrofurantoin, } \\
\text { tobramycin }\end{array}$ \\
\hline Madombidhza & 6199S & 6 & Positive & $\begin{array}{l}\text { Ampicillin, cefazolin, nitrofurantoin, } \\
\text { tobramycin }\end{array}$ \\
\hline Madombidhza & $6250 \mathrm{E}$ & 7 & Negative & Ampicillin \\
\hline Madombidhza & $6183 S$ & 10 & Negative & Ampicillin, cefazolin, ampicillin \\
\hline Madombidhza & $6184 S$ & 11 & Negative & Ampicillin \\
\hline Mankweng & $6242 \mathrm{E}$ & 8 & Negative & $\begin{array}{l}\text { Amikacin, ampicillin, cefazolin, } \\
\text { cefotaxime, nitrofurantoin, tobramycin }\end{array}$ \\
\hline Mankweng & $6258 \mathrm{E}$ & 7 & Negative & Ampicillin \\
\hline Mankweng & $6166 \mathrm{~S}$ & 1 & Negative & Ampicillin \\
\hline Mankweng & $6189 \mathrm{E}$ & 6 & Negative & Tobramycin \\
\hline Mankweng & $6182 S$ & 5 & Negative & Ampicillin \\
\hline Mankweng & $6255 \mathrm{E}$ & 11 & Negative & Nitrofurantoin, tobramycin \\
\hline Mankweng & $6172 S$ & 11 & Negative & $\begin{array}{l}\text { Amikacin, ampicillin, cefazolin, } \\
\text { cefotaxime, nitrofurantoin, tobramycin }\end{array}$ \\
\hline Musina & $6257 \mathrm{E}$ & 2 & Negative & Nitrofurantoin \\
\hline Musina & $6175 S$ & 4 & Negative & Ampicillin, cefazolin \\
\hline Musina & $6174 S$ & 3 & Negative & $\begin{array}{l}\text { Amikacin, ampicillin, cefazolin, } \\
\text { cefotaxime, nitrofurantoin, tobramycin }\end{array}$ \\
\hline Musina & $6239 \mathrm{E}$ & 5 & Negative & Ampicillin \\
\hline Musina & $6192 \mathrm{E}$ & 5 & Negative & Ampicillin \\
\hline Musina & $6190 \mathrm{E}$ & 6 & Negative & Ampicillin \\
\hline Musina & $6240 \mathrm{E}$ & 7 & Negative & Ampicillin \\
\hline Musina & $6247 \mathrm{E}$ & 9 & Negative & Tobramycin \\
\hline Musina & $6198 S$ & 4 & Negative & $\begin{array}{l}\text { Amikacin, ampicillin, cefazolin, } \\
\text { cefotaxime, nitrofurantoin, tobramycin }\end{array}$ \\
\hline
\end{tabular}




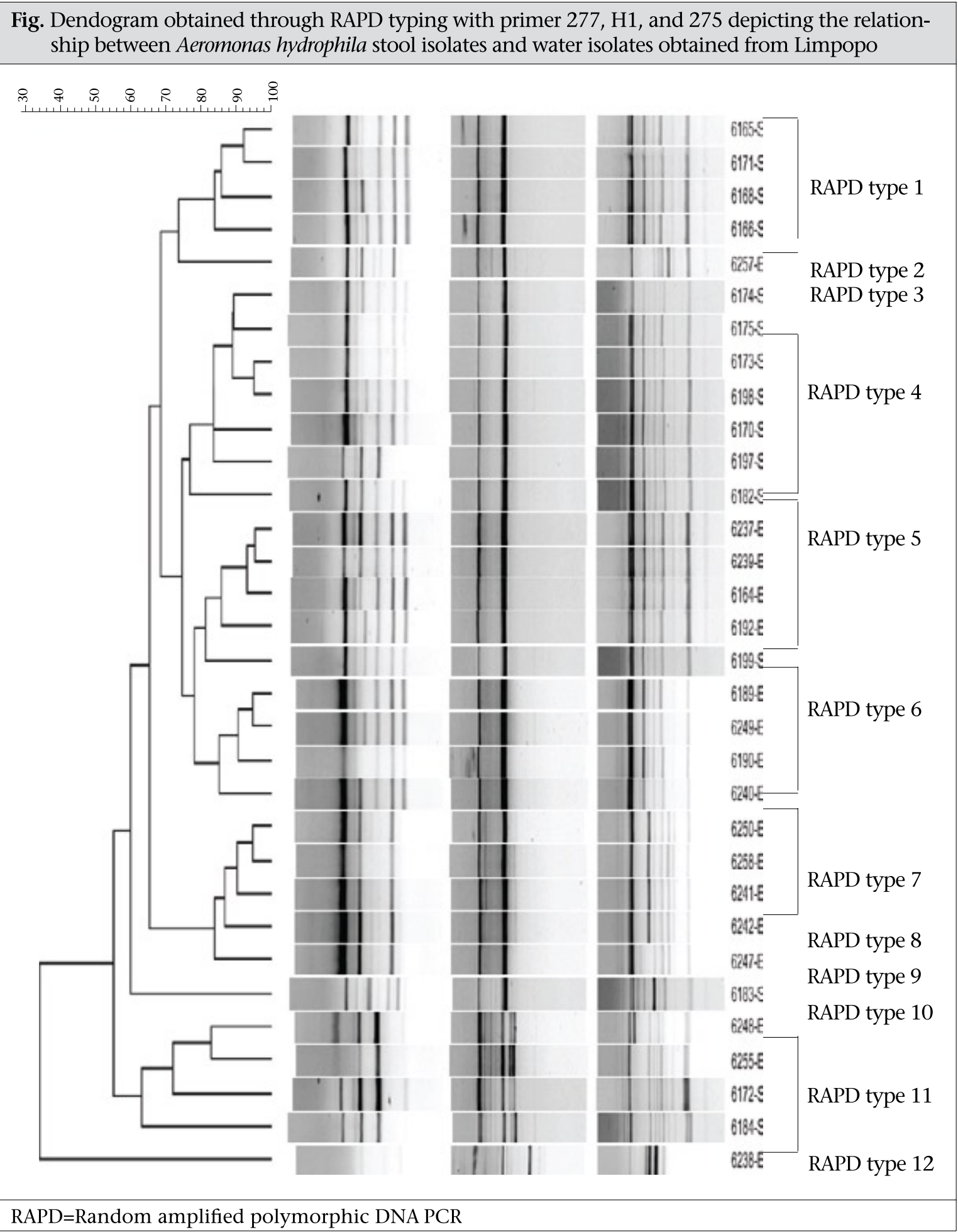

previous studies were not able to fully ascribe any genetic relatedness between the environmental and the clinical isolates. In the present study, three primers were used for RAPD fingerprinting of 32 A. hydrophila strains from stools and water samples from HIV and AIDS patients from five different localities approximately $400 \mathrm{~km}$ apart throughout the Limpopo province situated in the northern part of South Africa.

The banding patterns obtained in the present study were similar to those obtained by other researchers (5).

The results indicate a high genetic diversity in the A. hydrophila population in South Africa even 
though there was a mixture of environmental and clinical strains in some RAPD types probably due to separate introductions of the strains in the localities and poor health practices $(10,11)$. Other studies around the world, using genetic methods, have described high diversity in the A. hydrophila population $(12,13)$. Previous studies have indicated that homologs of a gene encoding a protein with lipase activity appeared to be widely distributed in Aeromonas strains, probably associating with the evolutionary genetic difference between clinical and environmental isolates of $A$. hydrophila (14). We have previously shown that clinical strains of A. hydrophila possessed pathogenic characteristics, such as haemolytic and haemagglutinating activities (6). It is, thus, possible that the environmental strains that had similar RAPD profiles as clinical strains might share pathogenic characteristics as well. Studies of $A$. hydrophila in Japan, using randomly-amplified polymorphic DNA-PCR (RAPDPCR), revealed one specific RAPD pattern group (G) that was associated only with strains from environmental sources. The comparison of isolates with pattern group $\mathrm{G}$ with a set of isolates derived from human blood showed low induction of cytotoxicity from those with RAPD pattern group G suggesting low virulence of these strains (13).

Although antibiotic resistance was common, statistical analysis using the chi-square test indicated that RAPD type 4 was more associated with amikacin resistance $\left(\chi^{2}=3.872 ; \mathrm{p}=0.049\right)$ and resistance to cefotaxime $\left(\chi^{2}=3.872 ; \mathrm{p}=0.049\right)$. Of all the strains tested, four were beta-lactamase-positive, of which two were of RAPD type 6. Statistical analysis indicated that RAPD type 6 was more associated with beta-lactamase production $\left(\chi^{2}=5.878, \mathrm{p}=0.015\right)$. Multiple drug resistance (MDR) defined as resistance of a specific strain to more than two antibiotics was common (41\%) among the strains tested. Statistical analysis indicated that RAPD type 4 was more associated with $\operatorname{MDR}\left(\chi^{2}=4.567, p=0.033\right)$. In a previous study, there was a correlation between the antibiotic resistance profile and the RAPD profiles of specific Aeromonas isolates (15).

In the present study, we did not find a clear differentiation between strains from different localities. RAPD type 1 was not found in Musina area but was found in all the other areas, including Belabela, Mankweng, and Madombidzha. Some RAPD genotypes included only one strain (Fig.). For example, RAPD genotype 2, type 3, and type 9 were all obtained from Musina area and included the environmental and clinical isolates while type 8,10 , and 12 were obtained from Mankweng, Madombidzha, and Belabela respectively. This diversity indicates the need for regular monitoring of Aeromonas strains for pathogenic characteristics and for the possibility of epidemic strains that could be circulating in the population. Studies of clinical and environmental ecotypes of Aeromonas in Mexico demonstrated the high intraspecific diversity within $A$. hydrophila and revealed a clear differentiation of strains according to their ecological origins (16). The same study also confirmed, based on the distribution of virulence-related genes, that $A$. hydrophila is a genetically-heterogeneous species that harbour ecotypes which have different pathogenic potentials to humans and other animals.

The results indicating the genetic similarity between the clinical and the environmental isolates of A. hydrophila in this study do not accord with those obtained in Switzerland that showed no genetic relationship between clinical and environmental strains (17). Studies in France also found that the water sampled in the hospital was not the source of infections for patients at the University Hospital in Marseille (18). With the high prevalence of HIV and AIDS in South Africa, patients might become more susceptible to infection by Aeromonas, and the possibility of acquiring the organisms from water is high and represents a great threat to human health. The results of the present study have revealed the possibility of an intricate web of relationship between isolates from stool and water samples in the Limpopo province of South Africa, indicating crosscontaminations and points to the need for effective control measures. The present study also showed that specific genotypes might be related to antibiotic resistance. Further studies on the cytotoxicity of strains under investigation are warranted and will further clarify the pathogenic characteristics of $A$. hydrophila strains in the region.

\section{ACKNOWLEDGEMENTS}

The authors are grateful to Dr. Jane Wright and Dr. Oliver Preisig of Inqaba Biotech Laboratory, Pretoria, South Africa, for their various roles in the implementation of the project. They are also immensely grateful to the National Research Foundation, South Africa, for financial assistance.

\section{REFERENCES}

1. Howard SP, Macintyre S, Buckley JT. Toxin. In: Austin B, Altwegg M, Gosling PJ, Joseph S, editors. The genus Aeromonas. Singapore: Wiley, 1996:267-86. 
2. Maalej S, Mahjoubi A, Elazri C, Dukan S. Simultaneous effects of environmental factors on motile Aeromonas dynamics in an urban effluent and in the natural seawater. Water Res 2003;7:2865-74.

3. Martínez JA, Pozo L, Almela M, Marco F, Soriano A, López $\mathrm{F}$ et al. Microbial and clinical determinants of time-to-positivity in patients with bacteraemia. Clin Microbiol Infect 2007;13:709-16.

4. Obi CL, Bessong PO. Diarrhoeagenic bacterial pathogens in HIV-positive patients with diarrhoea in rural communities of Limpopo province, South Africa. J Health Popul Nutr 2002;20:230-4.

5. Alavandi SV, Ananthan S, Pramod NP. Typing of Aeromonas isolates from children with diarrhoea \& water samples by randomly amplified polymorphic DNA polymerase chain reaction \& whole cell protein fingerprinting. Indian J Med Res 2001;113:85-97.

6. Obi CL, Ramalivhana J, Samie A, Igumbor EO. Prevalence, pathogenesis, and antibiotic susceptibility profiles of Aeromonas isolates from stool samples of patients in the Venda region of South Africa. J Health Popul Nutr 2007;25:428-35.

7. Balcázar JL, Vendrell D, de Blas I, Ruiz-Zarzuela I, Gironés O, Múzquiz JL. Quantitative detection of Aeromonas salmonicida in fish tissue by real-time PCR using self-quenched, fluorogenic primers. J Med Microbiol 2007;56:323-8.

8. Campbell M, Mahenthiralingam E, Speert DP. Evaluation of random amplified polymorphic DNA typing of Pseudomonas aeruginosa. J Clin Microbiol 2000;38:4614-5.

9. Zemanová E, Jirků M, Mauricio IL, Miles MA, Lukes J. Genetic polymorphism within the leishmania donovani complex: correlation with geographic origin. Am J Trop Med Hyg 2004;70:613-7.

10. Andargie G, Kassu A, Moges F, Tiruneh M, Huruy K. Prevalence of bacteria and intestinal parasites among food-handlers in Gondar town, northwest Ethiopia. J
Health Popul Nutr 2008;26:451-5.

11. Eshcol J, Mahapatra P, Keshapagu S. Is fecal contamination of drinking water after collection associated with household water handling and hygiene practices? A study of urban slum households in Hyderabad, India. J Water Health 2009;7:145-54.

12. Korbsrisate S, Trakulsomboon S, Damnin S, Gatedee J, Ratchtrachenchai OA, Leelaporn A et al. Genetic variations in Aeromonas hydrophila isolates from clinical and environmental sources in Thailand. Southeast Asian J Trop Med Public Health 2007;38:721-7.

13. Lee MF, Peng CF, Lin YH, Lin SR, Chen YH. Molecular diversity of class 1 integrons in human isolates of Aeromonas spp. from southern Taiwan. Jpn J Infect Dis 2008;61:343-9.

14. Watanabe N, Morita K, Furukawa T, Manzoku T, Endo E, Kanamori M. Sequence analysis of amplified DNA fragments containing the region encoding the putative lipase substrate-binding domain and genotyping of Aeromonas hydrophila. Appl Environ Microbiol 2004;70:145-51.

15. Gunsalam JW, Radu S, Benjamin PG, Selamat J, Robin T. Evidence of cross-contamination of Aeromonas hydrophila by fingerprinting: significance for food safety. J Food Safety 2006;26:302-12.

16. Aguilera-Arreola MG, Hernández-Rodríguez C, Zúñiga G, Figueras MJ, Castro-Escarpulli G. Aeromonas hydrophila clinical and environmental ecotypes as revealed by genetic diversity and virulence genes. FEMS Microbiol Lett 2005;242:231-40.

17. Moyer NP, Luccini GM, Holcomb LA, Hall NH, Altwegg M. Application of ribotyping for differentiating aeromonads isolated from clinical and environmental sources. Appl Environ Microbiol 1992;58:1940-4.

18. Davin-Regli A, Bollet C, Chamorey E, Colonna D'istria $\mathrm{V}$, Cremieux A. A cluster of cases of infections due to Aeromonas hydrophila revealed by combined RAPD and ERIC-PCR. J Med Microbiol 1998;47:499-504. 